\title{
ISOLATION AND IN VITRO ANTIOXIDANT ACTIVITY OF FLAVONOID FROM LINDERNIA CRUSTACEA (L) F. MUELL
}

\author{
SMRITI REKHA CHANDA DAS ${ }^{1 *}$, ABDUL BAQUEE AHMED ${ }^{1}$, DIBYENDU SHIL ${ }^{1}$, INDRANIL CHANDA ${ }^{2}$ \\ ${ }^{1}$ Department of Pharmacy, Girijananda Chowdhury Institute of Pharmaceutical Science, Guwahati, Assam, India. ${ }^{2}$ Department of \\ Examinations, Assam Science and Technology University, Guwahati, Assam, India. Email: das_smritirekha@rediffmail.com
}

Received: 02 April 2019, Revised and Accepted: 07 May 2019

\section{ABSTRACT}

Objective: The objective of the study was to investigate the antioxidant property of different extracts of Lindernia crustacea (L) F. Muell and isolate flavonoid from the potent extract and characterize it.

Methods: Isolation was carried out by flash chromatography using Toluene:acetic acid (4:1) as eluent. The isolated compound was characterized using spectroscopic methods. 2, 2'- diphenyl-1-picrylhydrazyl, ferric thiocyanate, thiobarbituric acid, and reducing power assay methods were followed for the antioxidant study.

Results: Characterization of the isolated compound confirms it as the flavonoid. Results of the antioxidant study showed that benzene extract has the highest antioxidant activity with a less $\mathrm{IC}_{50}$ value in comparison to ethyl acetate and ethanol extracts. The isolated compound showed significant antioxidant activity when compared with aspirin.

Conclusion: The results of the study suggest that L. crustacea (L) F. Muell is a source of flavonoid which has potent antioxidant activity.

Keywords: Lindernia crustacea (L) F. Muell, Flash chromatography, Flavonoid, Antioxidant activity, IC ${ }_{50}$ value.

(c) 2019 The Authors. Published by Innovare Academic Sciences Pvt Ltd. This is an open access article under the CC BY license (http://creativecommons. org/licenses/by/4. 0/) DOI: http://dx.doi.org/10.22159/ajpcr.2019.v12i6.33344

\section{INTRODUCTION}

Oxidation of an oxidizable substrate is significantly inhibited by the antioxidant substances when reacting concentration is less in comparison with that of the substrates [1]. Free radicals are reactive molecules and associated with aging, cancer, strokes, cardiac, DNA destruction, artery obstruction, and central nervous system disorders. There is an increased effort in research on the substances which can prevent the reactive oxygen species and thus can prevent such diseases [2,3]. Many research showed the positive role of flavonoids in the enzymatic action on the brain receptors, and effects on the central nervous system, which included neurodegenerative preventive action associated with Parkinson's and Alzheimer's diseases. Free radical scavenging and/or antioxidant activity of flavonoid is already proved by research works. Other pharmacological activities are also possessed by different types of flavonoids [4].

Globally, plants have been used traditionally as medicine to treat diseases, since ancient times [5]. As the natural sources have proved to be a resource of various potent chemical compounds, which are also pharmacologically active, so the global interest has grown to commercialize therapeutic drugs from the natural sources [6]. The potentiality of many such plants remains unexplored and unrevealed. One such plant is Lindernia crustacea (L) F. Muell, which belongs to family Linderniaceae. It is found throughout India in moist places such as river beds, rice fields, and open grassy places [7]. L. crustacea is also a popular and useful ethnomedicinal plant has been traditionally used throughout the world [8].

Previous research work showed the presence of flavonoid in the benzene, ethyl acetate, and ethanol extract of L. crustacea (L) F. Muell with comparatively potent pharmacological activities of benzene extract [9]. There is no research report found on the isolation of flavonoid from L. crustacea and its antioxidant property. Therefore, it was aimed to investigate in vitro antioxidant activity of the extracts and to isolate flavonoid from the potent extract followed by characterization and evaluation of in vitro antioxidant activity of the isolated flavonoid.

\section{MATERIALS AND METHODS}

\section{Materials}

Analytical grade reagents and solvents used in the study. Silica Gel-G (Merck, India), benzene (Merck, India), ethyl acetate (Merck, India), ethanol (Merck, India), 2, 2'- diphenyl-1-picrylhydrazyl (DPPH, SRL India), thiobarbituric acid (TBA) (Sigma-Aldrich, India), trichloroacetic acid (Merck, India), linoleic acid (Sigma-Aldrich, India), ammonium thiocyanate (SRL India), ascorbic acid (Merck, India), potassium ferricyanide (Merck, India), and ferric chloride (Merck, India) were used during the experimental protocol.

Isolation was carried out using flash chromatography (Teledyne ISCO Combi Flash $R_{f} 150$ ), and the melting point was determined using DSC (Perkin Elmer, DSC 4000). Instruments used for characterization of the isolated compound are: CHN Analyzer (Perkin Elmer, series II 2400), ultraviolet (UV) spectrophotometer (UV-1800, Shimadzu), infrared spectrophotometer (Alpha-E, Bruker), and 1H NMR and 13C NMR (Bruker Avance II 400 NMR spectrometer) where Tetramethylsilane (TMS) was used as internal reference standard, mass spectrometer (Waters, Q-TOF Micromass, ESI-MS, and mass spectrometer).

\section{Preparation of extract and phytochemical analysis}

The aerial parts of L. crustacea (L) F. Muell were collected from the paddy field of Dharapur, Guwahati, Assam, in the month of April and May and were authenticated by Dr. P.P. Baruah, HOD, Department of Botany, Gauhati University, Guwahati, Assam, as L. crustacea (L) F. Muell with family Linderniaceae and accession number was given for the specimen is 18063 . Shade-dried and coarsely powdered aerial parts of $L$. crustacea were subjected to successive extraction for $72 \mathrm{~h}$ by cold maceration in benzene, ethyl acetate, and ethanol. The solvents were filtered and evaporated using rotary evaporator (Buchi, 
Switzerland). Phytochemical screening was carried out as per the standard method [10].

\section{Isolation of flavonoid}

Phytochemical screening of all extracts showed the presence of flavonoid whereas benzene extract showed the highest antioxidant activity in comparison to ethyl acetate and ethanol extracts. Hence, it was aimed to isolate and characterize flavonoid from the benzene extract of L. crustacea. Thin-layer chromatography (TLC) was performed to optimize the solvent system for the separation of flavonoid [11]. Approximate $10 \mathrm{~g}$ of benzene extract was chromatographed in flash liquid chromatography with the TLC optimized eluent. The fractions which showed the same $R_{f}$ value were collected. The isolate was then dried using rotary evaporator and crystallized. The compound was further characterized using UV-visible spectrophotometry, DSC, Infra-red spectroscopy, mass spectroscopy, CHN analyzer, and NMR spectroscopy.

\section{Antioxidant assay}

\section{Preparation of test sample}

Extract samples were dissolved in DMSO to prepare a stock solution of $10 \mathrm{mg} / \mathrm{ml}$ concentration. For different concentration series of extracts, the required amount of stock solution was diluted with $95 \%$ methanol. For measuring antioxidant activity 10, 20, 35, 60, 125, 250, and $500 \mu \mathrm{g} / \mathrm{ml}$, concentrations of the extracts were studied. The isolated compound was dissolved in $95 \%$ methanol to give the concentrations of $10,20,35,60$, and $125 \mu \mathrm{g} / \mathrm{ml}$.

\section{Preparation of reference standard solution}

The reference standard ascorbic acid were dissolved in $95 \%$ methanol to prepare the concentrations of $10,20,35,60$, and $125 \mu \mathrm{g} / \mathrm{ml}$.

\section{DPPH assay}

DPPH assay was performed as per the method described by BrandWilliams, [12] to measure in vitro radical scavenging activity. DPPH $(24 \mathrm{mg}$ ) was dissolved in $100 \mathrm{ml}$ methanol to prepare the stock solution, and it was kept at $20^{\circ} \mathrm{C}$ [13]. To prepare a working solution, the DPPH stock solution was diluted with methanol and adjusted to an absorbance at $517 \mathrm{~nm}$ of about $0.98 \pm 0.02$. To $100 \mu \mathrm{l}$ of each sample, $3 \mathrm{ml}$ of the DPPH working solution was added. The content was shaken and then incubated in the dark for $15 \mathrm{~min}$ at room temperature. The absorbance of the resulting solutions was measured at $517 \mathrm{~nm}$ [14]. The control solution was prepared as mentioned above but without the addition of extract or isolated compound. The percentage of scavenging effect was calculated as per the following equation:

$$
\text { Scavenging effect }(\%)=\frac{\left(A_{\text {control }}-A_{\text {sample }}\right)}{A_{\text {contol }}} \times 100
$$

Where, "A" denotes as the absorbance

$\mathrm{IC}_{50}$ value (sample concentration that produced $50 \%$ inhibition) for each sample was calculated.

\section{Ferric thiocyanate (FTC) method}

Test and reference samples in different concentrations $(1 \mathrm{ml})$ were mixed with of $4 \mathrm{ml}$ of absolute ethanol, $4.1 \mathrm{ml}$ linoleic acid $(2.51 \%)$ in absolute ethanol, $8.0 \mathrm{~mL} 0.02 \mathrm{M}$ phosphate buffer $(\mathrm{pH} 7.0)$, and $3.9 \mathrm{ml}$ distilled water. The mixture was kept in an oven which was maintained at $40^{\circ} \mathrm{C}$. From this, $0.1 \mathrm{ml}$ was transferred to a tube and $9.7 \mathrm{ml}$ aqueous ethanol $(75 \% \mathrm{v} / \mathrm{v})$, followed by $0.1 \mathrm{ml}$ aqueous ammonium thiocyanate $(30 \% \mathrm{v} / \mathrm{v})$ and $0.1 \mathrm{ml}$ of $0.02 \mathrm{M}$ ferrous chloride (prepared in $3.5 \%$ hydrochloric acid) were added [15]. The absorbance was measured after $3 \mathrm{~min}$ at $500 \mathrm{~nm}$ and after every $24 \mathrm{~h}$, until reached its maximum value. Mixture without the extract or isolated compound was used as the control.
Percentage $(\%)$ of Inhibition $=\frac{\left(\mathrm{A}_{\text {control }}-\mathrm{A}_{\text {sample }}\right)}{\mathrm{A}_{\text {contol }}} \times 100$

Where, " $\mathrm{A}$ " denotes as the absorbance

$\mathrm{IC}_{50}$ value for each sample was calculated

\section{TBA method}

The method of Kikuzaki and Nakatani [15] was followed for this assay

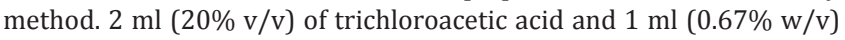
of TBA were added to $2 \mathrm{ml}$ of reactions mixture, which was prepared and incubated as described in the FTC method. The final mixture was kept for 10 min on a boiling water bath. After cooling, the mixture was centrifuged for $20 \mathrm{~min}$ at $3000 \mathrm{rpm}$. On every $24 \mathrm{~h}$, the absorbance was measured at $552 \mathrm{~nm}$ and recorded when it has reached its maximum value. Mixture without the extract or isolated compound was used as the control.

Antioxidant activity was described by percentage inhibition and calculated using the following equation:

$$
\text { Percentage }(\%) \text { ofInhibition }=\frac{\left(A_{\text {control }}-A_{\text {sample }}\right)}{A_{\text {contol }}} \times 100
$$

Where, "A" denotes as the absorbance

$\mathrm{IC}_{50}$ value for each sample was calculated

\section{Reducing power assay}

A substance with reduction potential reacts with potassium ferricyanide $(\mathrm{Fe} 3+)$ to form potassium ferrocyanide $(\mathrm{Fe} 2+)$. This reacts with ferric chloride to form a ferric ferrous complex which shows maximum absorption at $700 \mathrm{~nm}$. This assay was performed as per the method described by Oyaizu [16]. Different concentrations of the samples $(1 \mathrm{ml})$ were mixed with $2.5 \mathrm{ml}$ phosphate buffer $(0.2 \mathrm{M}$, $\mathrm{pH} 6.6)$ and $2.5 \mathrm{ml}$ potassium ferricyanide $(1 \% \mathrm{w} / \mathrm{v})$. The mixture was incubated for $20 \mathrm{~min}$ at $50^{\circ} \mathrm{C}$ and after cooling $2.5 \mathrm{ml}$ trichloroacetic acid $(10 \% \mathrm{v} / \mathrm{v})$ was added [17]. It was centrifuged for $10 \mathrm{~min}$ at $3000 \mathrm{rpm}$. Then, $2.5 \mathrm{ml}$ of the supernatant was mixed with $2.5 \mathrm{ml}$ of distilled water and freshly prepared $0.5 \mathrm{ml}$ ferric chloride solution $(0.1 \% \mathrm{w} / \mathrm{v})$. After $10 \mathrm{~min}$, the absorbance of the resulting mixture was measured at $700 \mathrm{~nm}$

\section{Data analysis}

Experiments were performed in triplicate. Result data were calculated as the means with standard deviation. The $\mathrm{IC}_{50}$ values were calculated by regression analysis using MS Excel.

\section{RESULTS}

Benzene extract showed a maximum yield of $12.43 \%$, whereas ethyl acetate and ethanol extract showed $10.24 \%$ and $6.40 \%$, respectively. The presence of flavonoid, phenolic compound, and tannins in all three extracts was indicated by the phytochemical analysis. Toluene:acetic acid (4:1) was optimized as the solvent system to separate flavonoid which confirmed by aluminum chloride spraying reagent. Similar $R_{f}$ value of 0.31 was shown by the fraction no. 27-38 obtained from flash chromatography which was pulled together and crystallized.

\section{Characterization of isolated compound}

Isolated compound, sample code given as LCF-I, obtained as fine yellow crystals; melting point 314.32; yield $2.12 \% \mathrm{w} / \mathrm{w}$; UV- visible (Methanol) $\lambda_{\max }=371.80,255.40 \mathrm{~nm}$ (Table 1); IR absorption peaks: $3263 \mathrm{~cm}^{-1}, 1664 \mathrm{~cm}^{-1}, 1609 \mathrm{~cm}^{-1}, 1435 \mathrm{~cm}^{-1}, 1352 \mathrm{~cm}^{-1}, 1310$ $\mathrm{cm}^{-1}, 1206 \mathrm{~cm}^{-1}, 1238 \mathrm{~cm}^{-1}, 1160 \mathrm{~cm}^{-1}$; CHN analysis: carbon $82.608 \%$, hydrogen $2.248 \%$, oxygen $15.144 \% ; \mathrm{m} / \mathrm{z} 302.24[\mathrm{M}+\mathrm{H}]+$ and $\mathrm{m} / \mathrm{z} 301.22$ [M-H]-; 1H-NMR (400 MHz, DMSO), $\delta$ (ppm), $9.34(1 \mathrm{H}, \mathrm{s}, \mathrm{H}-3), 12.48(1 \mathrm{H}$, s, OH-5), 6.19 (1H, d, J=2.44 Hz, H-6), $10.78(1 \mathrm{H}, \mathrm{s}, \mathrm{OH}-7), 6.41(1 \mathrm{H}, \mathrm{d}$, 
$J=1.56 \mathrm{~Hz}, \mathrm{H}-8), 7.68\left(1 \mathrm{H}, \mathrm{d}, J=2.04 \mathrm{~Hz}, \mathrm{H}-2^{\prime}\right), 9.34\left(1 \mathrm{H}, \mathrm{s}, \mathrm{H} 3^{\prime}\right), 9.57(1 \mathrm{H}, \mathrm{s}$, OH-4'), $6.90\left(1 \mathrm{H}, \mathrm{d}, J=8.44 \mathrm{~Hz}, \mathrm{H}-5^{\prime}\right), 7.55\left(1 \mathrm{H}, \mathrm{dd}, J=1.32 / 9.68 \mathrm{~Hz}, \mathrm{H}-6^{\prime}\right)$; 13C-NMR (400 MHz, DMSO) $\delta$ (ppm), 147.64 (C-2), 135.69 (C-3), 175.79 (C-4), 160.68 (C-5), 98.15 (C-6), 163.84 (C-7), 93.32 (C-8), 156.09 (C-9), 102.97 (C-10), 121.93 (C-1'), 115.03 (C-2'),145.00 (C-3'),146.74 (C-4'), $115.56\left(C^{-}-5^{\prime}\right), 119.95\left(C-6^{\prime}\right)$. The findings of NMR spectrum confirmed by comparison with literature data $[18,19]$. LCF-I was identified as 2-(3',4'-dihydroxy phenyl)-3,5,7-trihydroxy chromen- 4-one.

\section{Antioxidant assay}

DPPH assay

Fig. 1 shows the DPPH radical scavenging activity of different extracts and the isolated compound (LCF-I) of L. crustacea compared with aspirin. It was observed that benzene extract produced the highest activity, followed by ethyl acetate and ethanol extracts, respectively (Table 2). At the concentration of $500 \mu \mathrm{g} / \mathrm{ml}$, the scavenging activity of benzene extract reached $70.31 \pm 0.02 \%$, but at the same concentration, that of ethyl acetate and ethanol extracts were $53.21 \pm 0.09 \%$ and $37.45 \pm 0.10 \%$, respectively. LCF-I showed $79.66 \pm 0.06 \%$ scavenging activity at the concentration of $125 \mu \mathrm{g} / \mathrm{ml}$ which is comparable with the $88.77 \pm 0.10 \%$ scavenging activity of aspirin at the same concentration. The result also showed that LCF-I has less $\mathrm{IC}_{50}$ value which was comparable with the aspirin (Table 3).

FTC method and TBA method

The antioxidant activity of extracts and LCF-I was measured to study lipid peroxidation by FTC and TBA methods and results represented in Tables 2 and 3. Benzene extract showed the highest antioxidant activity at $500 \mu \mathrm{g} /$ $\mathrm{ml}$ concentration in both FTC and TBA methods, among all three extracts, whereas LCF-I at the concentration of $125 \mu \mathrm{g} / \mathrm{ml}$ showed $82.11 \pm 0.06 \%$ and $85.20 \pm 0.03 \%$ inhibition, respectively, in FTC and TBA methods (Figs. 2 and 3). Ascorbic acid showed $93.33 \pm 0.02 \%$ inhibition in FTC and $90.42 \pm 0.08 \%$ inhibition in TBA method at the concentration of $125 \mu \mathrm{g} / \mathrm{ml}$.

\section{Reducing power assay}

All three extracts of $L$. crustacea showed increased reducing power activity with the increase in the concentrations (Table 2). Benzene extract showed the highest reducing power at $500 \mu \mathrm{g} / \mathrm{ml}$ concentration

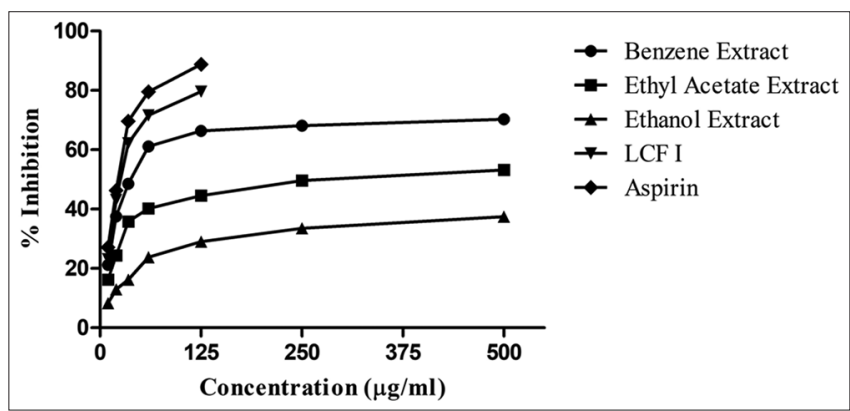

Fig. 1: Antioxidant activities by DPPH radical scavenging method

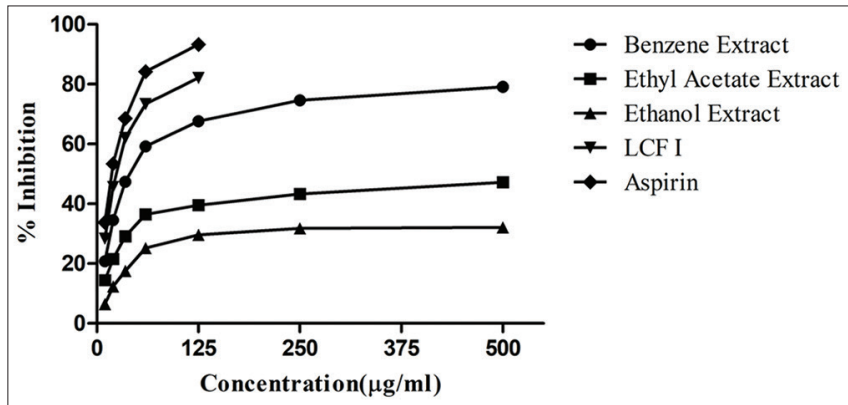

Fig. 2: Antioxidant activities by ferric thiocyanate method

Table 1: UV-visible absorption peaks of LCF-I in methanol and after addition of shifting reagents

\begin{tabular}{llllll}
\hline \multicolumn{5}{c}{ Absorption peak (nm) } \\
\hline $\mathbf{C H}_{3} \mathbf{O H}$ & $\mathbf{N a O M e}$ & $\mathbf{A l C l}_{3}$ & $\mathbf{A l C l}_{3} / \mathbf{H C l}$ & $\mathbf{N a O A c}$ & $\mathbf{N a O A c}_{\mathbf{H}} \mathbf{H}_{3} \mathbf{B O}_{3}$ \\
\hline 371.80 & 327.50 & 443.60 & 432.00 & 394.90 & 388.04 \\
255.40 & & 269.20 & 261.40 & 383.40 & 270.12 \\
& & & 273.40 & \\
\hline
\end{tabular}

UV: Ultraviolet, $\mathrm{AlCl}_{3}$ Aluminum chloride, NaOAc: Sodium acetate, NaOMc: Sodium methoxide

Table 2: In vitro antioxidant activities of different extracts and isolated compound of Lindernia crustacea (L) F. Muell

\begin{tabular}{|c|c|c|c|c|c|c|c|c|c|}
\hline \multirow[t]{2}{*}{ Sl. No } & \multirow[t]{2}{*}{ Extracts } & \multirow[t]{2}{*}{ Study Model } & \multicolumn{7}{|c|}{ Antioxidant activity } \\
\hline & & & $10 \mu \mathrm{g} / \mathrm{ml}$ & $20 \mu \mathrm{g} / \mathrm{ml}$ & $35 \mu \mathrm{g} / \mathrm{ml}$ & $60 \mu \mathrm{g} / \mathrm{ml}$ & $125 \mu \mathrm{g} / \mathrm{ml}$ & $250 \mu \mathrm{g} / \mathrm{ml}$ & $500 \mu \mathrm{g} / \mathrm{ml}$ \\
\hline \multirow[t]{3}{*}{1.} & \multirow[t]{3}{*}{ Benzene } & DPPH & $21.17 \pm 0.05$ & $37.55 \pm 0.11$ & $48.51 \pm 0.07$ & $61.15 \pm 0.09$ & $66.35 \pm 0.05$ & $68.10 \pm 0.12$ & $70.31 \pm 0.02$ \\
\hline & & FTC & $20.76 \pm 0.04$ & $34.57 \pm 0.04$ & $47.41 \pm 0.07$ & $59.22 \pm 0.08$ & $67.66 \pm 0.10$ & $74.59 \pm 0.11$ & $79.10 \pm 0.13$ \\
\hline & & $\mathrm{RP}$ & $0.124 \pm 0.05$ & $0.278 \pm 0.03$ & $0.361 \pm 0.07$ & $0.592 \pm 0.07$ & $0.777 \pm 0.06$ & $0.892 \pm 0.05$ & $1.186 \pm 0.04$ \\
\hline \multirow[t]{4}{*}{2.} & \multirow[t]{4}{*}{ Ethyl Acetate } & DPPH & $16.21 \pm 0.08$ & $24.38 \pm 0.12$ & $35.78 \pm 0.08$ & $40.17 \pm 0.10$ & $44.51 \pm 0.06$ & $49.6 \pm 0.05$ & $53.21 \pm 0.09$ \\
\hline & & TBA & $13.52 \pm 0.05$ & $19.11 \pm 0.04$ & $24.22 \pm 0.04$ & $29.74 \pm 0.14$ & $32.11 \pm 0.11$ & $35.81 \pm 0.12$ & $37.27 \pm 0.09$ \\
\hline & & FTC & $14.46 \pm 0.12$ & $21.55 \pm 0.03$ & $29.12 \pm 0.07$ & $36.47 \pm 0.06$ & $39.53 \pm 0.13$ & $43.33 \pm 0.06$ & $47.20 \pm 0.08$ \\
\hline & & $\mathrm{RP}$ & $0.097 \pm 0.10$ & $0.133 \pm 0.02$ & $0.209 \pm 0.09$ & $0.366 \pm 0.11$ & $0.482 \pm 0.07$ & $0.532 \pm 0.06$ & $0.601 \pm 0.06$ \\
\hline \multirow[t]{4}{*}{3.} & \multirow[t]{4}{*}{ Ethanol } & DPPH & $8.25 \pm 0.14$ & $12.96 \pm 0.05$ & $16.22 \pm 0.10$ & $23.78 \pm 0.15$ & $29.08 \pm 0.07$ & $33.55 \pm 0.06$ & $37.45 \pm 0.10$ \\
\hline & & TBA & $10.25 \pm 0.04$ & $15.41 \pm 0.10$ & $19.16 \pm 0.13$ & $26.50 \pm 0.05$ & $33.23 \pm 0.03$ & $37.14 \pm 0.08$ & $41.81 \pm 0.08$ \\
\hline & & FTC & $6.44 \pm 0.08$ & $12.36 \pm 0.04$ & $17.52 \pm 0.14$ & $25.2 \pm 0.06$ & $29.61 \pm 0.12$ & $31.77 \pm 0.07$ & $32.11 \pm 0.06$ \\
\hline & & $\mathrm{RP}$ & $0.045 \pm 0.05$ & $0.089 \pm 0.10$ & $0.152 \pm 0.02$ & $0.220 \pm 0.08$ & $0.316 \pm 0.05$ & $0.379 \pm 0.08$ & $0.430 \pm 0.04$ \\
\hline \multirow[t]{3}{*}{4.} & \multirow[t]{3}{*}{ LCF-I } & DPPH & $23.14 \pm 0.06$ & $43.15 \pm 0.08$ & $62.23 \pm 0.11$ & $71.62 \pm 0.04$ & $79.66 \pm 0.06$ & - & - \\
\hline & & TBA & $28.32 \pm 0.05$ & $46.95 \pm 0.07$ & $63.14 \pm 0.09$ & $78.63 \pm 0.08$ & $85.20 \pm 0.03$ & - & - \\
\hline & & FTC & $28.41 \pm 0.12$ & $45.65 \pm 0.05$ & $62.06 \pm 0.09$ & $73.38 \pm 0.07$ & $82.11 \pm 0.06$ & - & - \\
\hline \multirow[t]{4}{*}{5.} & \multirow[t]{4}{*}{ Ascorbic acid } & DPPH & $27.09 \pm 0.08$ & $46.27 \pm 0.09$ & $69.65 \pm 0.03$ & $79.51 \pm 0.04$ & $88.77 \pm 0.10$ & - & - \\
\hline & & TBA & $28.03 \pm 0.05$ & $52.22 \pm 0.05$ & $71.87 \pm 0.07$ & $81.03 \pm 0.06$ & $90.42 \pm 0.08$ & - & - \\
\hline & & FTC & $33.77 \pm 0.07$ & $53.36 \pm 0.05$ & $68.54 \pm 0.04$ & $84.23 \pm 0.09$ & $93.33 \pm 0.02$ & - & - \\
\hline & & $\mathrm{RP}$ & $0.723 \pm 0.03$ & $0.925 \pm 0.04$ & $1.286 \pm 0.07$ & $1.412 \pm 0.06$ & $1.732 \pm 0.08$ & - & - \\
\hline
\end{tabular}

Values are mean+SEM of 3 replicates. FTC: Ferric thiocyanate, TBA: Thiobarbituric acid 
Table 3: IC ${ }_{50}$ values from DPPH, TBA, and FTC method

\begin{tabular}{llll}
\hline Sl. No. & Activity & Extracts/Compound & IC $_{\mathbf{5 0}}(\boldsymbol{\mu g} / \mathbf{m l})$ \\
\hline 1 & DPPH & Ascorbic acid & 23.69 \\
& & LCF-I & 35.76 \\
& Benzene Extract & 96.2 \\
& Ethyl Acetate Extract & 352.48 \\
& & Ethanol Extract & 654.38 \\
& \multirow{4}{*}{ TBA } & Ascorbic acid & 17.5 \\
& & LCF-I & 26.11 \\
& & Benzene Extract & 89.76 \\
3 & Ethyl Acetate Extract & 728.37 \\
& & Ethanol Extract & 562.28 \\
& \multirow{3}{*}{ FTC } & Ascorbic acid & 13.58 \\
& & LCF-I & 29.65 \\
& Benzene Extract & 92.48 \\
& & Ethyl Acetate Extract & 463.03 \\
& & Ethanol Extract & 807.76 \\
\hline
\end{tabular}

FTC: Ferric thiocyanate, TBA: Thiobarbituric acid

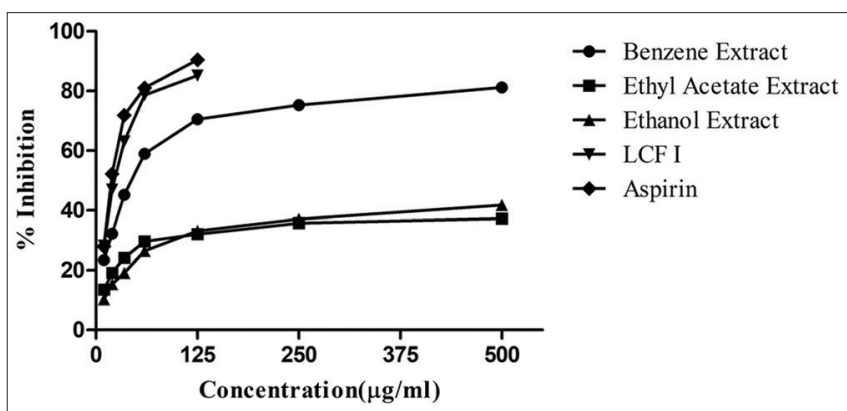

Fig. 3: Antioxidant activities by thiobarbituric acid method

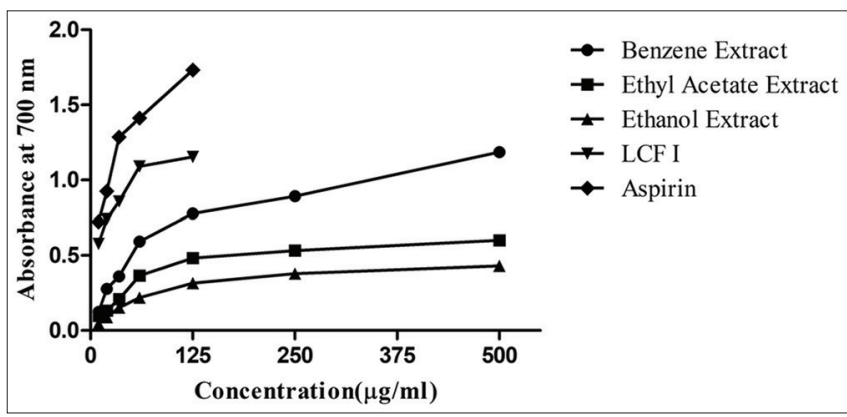

Fig. 4: Antioxidant activities by reducing power assay method

than the ethyl acetate and ethanol extracts (Fig. 4). Although ascorbic acid showed the highest reducing power, LCF-I showed a comparable result at the same concentration $(125 \mu \mathrm{g} / \mathrm{ml})$.

\section{DISCUSSION}

Infrared spectra of LCF-I showed OH stretching vibration of phenol, which was indicated by the absorption peak at around $3263 \mathrm{~cm}^{-1}$. The absorption peak at $1664 \mathrm{~cm}^{-1}$ was observed due to $\mathrm{C}=0$ aryl ketonic stretching vibrations. The peak positioned at $1609 \mathrm{~cm}^{-1}$ due to $\mathrm{C}-\mathrm{C}$ and $1435 \mathrm{~cm}^{-1}$ due to the presence of the aromatic group [20]. The absorption peak at $1352 \mathrm{~cm}^{-1}$ was observed due to $\mathrm{OH}$ bending vibrations of phenols. Absorption peaks at $1310 \mathrm{~cm}^{-1}$ and the peaks at the lower frequencies between $950 \mathrm{~cm}^{-1}$ and $634 \mathrm{~cm}^{-1}$ were observed due to the presence of $\mathrm{C}-\mathrm{H}$ bending vibrations of aromatic hydrocarbons. C-O stretching vibrations of phenols and aryl ether were indicated by the presence of peaks at $1206 \mathrm{~cm}^{-1}$ and $1238 \mathrm{~cm}^{-1}$, respectively. Due to the presence of C-CO-C stretching and bending vibrations of ketones, the absorption peak at $1160 \mathrm{~cm}^{-1}$ was observed [21].
The UV-visible spectrum of methanolic $\left(\mathrm{CH}_{3} \mathrm{OH}\right)$ solution of LCF-I showed two major absorption bands at $371.80 \mathrm{~nm}$ (band-I) due to cinnamoyl system and $255.40 \mathrm{~nm}$ (band-II) due to benzoyl system. This confirmed the flavonol structure in LCF-I. From the results of the addition of different shifting reagents in a methanolic solution of LCF-I (Table 1), this is revealed that a complex was formed by aluminum chloride $\left(\mathrm{AlCl}_{3}\right)$ with the hydroxyl group at C-3 or/and C-5 and also with the ketone group at C-4 of the flavonol structure. The flavonol-aluminum complex produces a bathochromic shift. An acid-labile complex was also formed with the catechol functional group which was dissociated on the addition of hydrochloric acid, and produced a hypsochromic shift, compared to the aluminum chloride spectrum. Sodium acetate ( $\mathrm{NaOAc}$ ) ionizes the flavonols with a free 7- hydroxyl and exhibiting a Band II shift. Addition of sodium methoxide degenerated of the band I which indicates free hydroxyl groups at C-3 and C-4'. Hypsochromic shifts with $\mathrm{AlCl}_{3} / \mathrm{HCl}$ and a bathochromic shift in band-I with NaOAc and boric acid $\left(\mathrm{NaOAc} / \mathrm{H}_{3} \mathrm{BO}_{3}\right)$ indicated the presence of $3,3^{\prime}, 4^{\prime}$ trihydroxy system in LCF-I [22].

It is found that due to the hydrogen-donating ability of the antioxidants, they exert an effect on DPPH [23-25]. Although the DPPH radical scavenging abilities of LCF-I were found to be lower than that of the aspirin, it was evident that LCF-I showed remarkable hydrogen-donating ability. This property of LCF-I served as free radical scavengers which acted possibly as primary antioxidants. Thus, the isolated compound from the benzene extract of L. crustacea found to be scavenged DPPH radical $[26,27]$. The amount of peroxide produced at the initial stages of lipid oxidation is measured in the FTC method [28], whereas the amount of peroxide produced in the secondary stages of lipid peroxidation is measured by the TBA method $[29,30]$. The higher antioxidant activity of showed by LCF-I in the TBA method than in FTC method indicated that, the peroxide amount produced at the initial stages of lipid oxidation, is lower than the second stage [31]. The less $\mathrm{IC}_{50}$ values (Table 3 ) of 29.65 and 26.11 for FTC and TBA methods, respectively, suggested better effect against lipid peroxidation which was comparable with ascorbic acid [26].

In reducing power assay, ferric/ferricyanide complex is reduced to the ferrous form in the presence of antioxidants. This reducing capacity of the sample is the indicator of antioxidant property, and an increase in reducing the power of the sample is indicated by the increase in absorbance [32]. This is used to find out the ability of an antioxidant sample to donate electron [33,34]. Many research reports have shown that there is a correlation between reducing power and antioxidant activity $[35,36]$. The result revealed that LCF-I donates an electron to react with free radicals which convert to a stable product and thus terminates radical chain reaction [37]. This fact indicates the strong antioxidant activity of LCF-I.

\section{CONCLUSION}

The results of the study showed that benzene extract of $L$. crustacea (L) F. Muell and the isolated flavonoid has potent antioxidant activity whereas ethyl acetate and ethanol extracts showed weak antioxidant activity. The study results suggest that benzene extract of $L$. crustacea plant is a potential natural antioxidant source. Although the isolated compound is characterized and identified, the mechanisms of antioxidant activity need to be further studied.

\section{ACKNOWLEDGMENTS}

The facilities for conducting this research work from the authorities of Gauhati University, Guwahati and Girijananda Chowdhury Institute of Pharmaceutical Science, Guwahati, are thankfully acknowledged.

\section{AUTHOR'S CONTRIBUTIONS}

Smriti Rekha Chanda Das has contributed to the concept and design of the research work, experimental studies, data acquisition, data analysis, and manuscript writing; Abdul Baquee Ahmed has supervised and 
involved in the concept and design of the research work, experimental studies and manuscript revision; Dibyendu Shil has helped in experimental studies, data acquisition, and data analysis; Indranil Chanda has contributed in data analysis, interpretation of spectral data and manuscript revision.

\section{CONFLICTS OF INTEREST}

No conflicts of interest are associated with this work.

\section{REFERENCES}

1. Halliwell B, Gutteridge JM. Free Radicals in Biology and Medicine. $3^{\text {rd }}$ ed. United Kingdom: Oxford University Press; 1999.

2. Rakesh SU, Priyanka RP, Sagar RM. Use of natural antioxidants to scavenge free radicals: A major cause of diseases. Int J Pharm Tech Res 2010;2:1074-81.

3. Kapadiya DB, Dabhi BK, Aparnathi KD. Spices and herbs as a source of natural antioxidants for food. Int J Curr Microbiol Appl Sci 2016;5:280-8

4. Panche AN, Diwan AD, Chandra SR. Flavonoids: An overview. J Nutri Sci 2016;5:e47:1-15.

5. Ekor M. The growing use of herbal medicines: Issues relating to adverse reactions and challenges in monitoring safety. Front Pharmacol 2014;4:177

6. Afsar T, Razak S, Shabbir M, Khan MR. Antioxidant activity of polyphenolic compounds isolated from ethyl-acetate fraction of Acacia hydaspica R. Parker. Chem Cent J 2018;12:5.

7. Anonymous. The Wealth of India-Raw Materials. New Delhi, India: Council of Scientific and Industrial Research; 2005.

8. Usher G. A Dictionary of Plants used by Man. London: Constable and Company Ltd.; 1974.

9. Chanda SR, Ahmed AB, Saha D, Chanda I. Scientific evidence of Lindernia crustacea (L) F. Muell, an indigenous plant: A folklore medicine used traditionally. Int Res J Pharm 2019;10:176-83.

10. Trease GE, Evans WC. Pharmacognosy. Oxford: Alden Press; 1996

11. Wagner H, Bladt S, Zgainski EM. Plant Drug Analysis: A Thin-Layer Chromatography Atlas. Heidelberg: Springer-Verlag; 1996.

12. Brand-Williams W, Cuvelier ME, Berset C. Use of the free radical method to evaluate antioxidant activity. LWT 1995;28:25-30.

13. Bokhari J, Khan MR, Haq IU. Assessment of phytochemicals, antioxidant, and anti-inflammatory potential of Boerhavia procumbens banks ex Roxb. Toxicol Ind Health 2016;32:1456-66.

14. Zhao T, Zhang Q, Qi H, Zhang H, Niu X, Xu Z, et al. Degradation of porphyran from Porphyra haitanensis and the antioxidant activities of the degraded porphyrans with different molecular weight. Int J Biol Macromol 2006:38:45-50.

15. Kikuzaki H, Nakatani N. Antioxidant effect of some ginger constituents. J Food Sci 1993;58:1407-10

16. Oyaizu M. Studies on the product of browning reaction prepared from glucose amine. Jpn J Nutr 1986;44:307-15.

17. Mu H, Zhang A, Zhang W, Cui G, Wang S, Duan J, et al. Antioxidative properties of crude polysaccharides from Inonotus obliquus. Int J Mol Sci 2012;13:9194-206.

18. Wang J, Gao H, Zhao J, Wang Q, Zhou L, Han J, et al. Preparative separation of phenolic compounds from Halimodendron halodendron by high-speed counter-current chromatography. Molecules 2010;15:5998-6007.

19. Zhu ZJ, Pan R, Si JY, Fu Y, Huang QQ. Study on the chemical constituents of Bupleurum bicaule Helm (in Chinese with English abstract). Nat Prod Res Dev 2008;20:833-5.

20. Bharathi S, Devasena T, Arivarasan A, Pachaiappan R. Extraction and isolation of flavonoid quercetin from the leaves of Trigonella foenum-graecum and their anti-oxidant activity. Int J Pharm Pharm Sci $2016 ; 8: 120-4$

21. Chourasiya A, Upadhayay A, Shukla RN. Isolation of quercetin from the leaves of Azadirachta indica and antidiabetic study of the crude extracts. J Pharm Biomed Sci 2012;25:179-81.

22. Mabry TJ, Markham KR, Thomas MB. The Systematic Identification of Flavonoids. New York: Springer Verlag; 1970

23. Kurechi T, Kikugawa K, Kato T. Studies on the antioxidants. XIII. Hydrogen donating capability of antioxidants to 2, 2-diphenyl-1picrylhydrazyl. Chem Pharm Bull 1980;28:2089-93.

24. Nounagnon MS, Dah-nouvlessounon D, N'Tcha C, Legba B, Babamoussa F, Adjanohoun A, et al. Phytochemistry and biological activities of Crateva adansonii extracts. Int J Pharm Pharm Sci 2018;10:62-7.

25. Sumita D, Maitry P, Nirali P. Antioxidant activities of some less utilized edible fruits. Int J Curr Pharm Res 2017;9:28-31.

26. Phongpaichit S, Nikom J, Rungjindamai N, Sakayaroj J, HutadilokTowatana N, Rukachaisirikul V, et al. Biological activities of extracts from endophytic fungi isolated from Garcinia plants. FEMS Immunol Med Microbiol 2007;51:517-25.

27. Renuka K, Devi VR, Subramanian SP. Phytochemical screening and evaluation of in vitro antioxidant potential of immature Palmyra Palm (Borassus flabellifer Linn.) Fruits. Int J Pharm Pharm Sci 2018;10:77-83.

28. Saha K, Lajis NH, Israf DA, Hamzah AS, Khozirah S, Khamis S, et al. Evaluation of antioxidant and nitric oxide inhibitory activities of selected Malaysian medicinal plants. J Ethnopharmacol 2004;92:263-7.

29. Rahmat A, Kumar V, Fong LM, Endrini S, Sani HA. Determination of total antioxidant activity in three types of local vegetables shoots and the cytotoxic effect of their ethanolic extracts against different cancer cell lines. Asia Pac J Clin Nutr 2003;12:292-5.

30. Aiyegoro OA, Okoh AI. Preliminary phytochemical screening and in vitro antioxidant activities of the aqueous extract of Helichrysum longifolium DC. BMC Complement Altern Med 2010;10:21.

31. Rezaeizadeh A, Zuki AB, Abdollahi M, Goh YM, Noordin MM, Hamid M, et al. Determination of antioxidant activity in methanolic and chloroformic extracts of Momordica charantia. Afr J Biotechnol 2011;10:4932-40.

32. Umamaheswari M, Chatterjee TK. In vitro antioxidant activities of the fractions of Coccinia grandis L. Leaf extract. Afr J Tradit Complement Altern Med 2007;5:61-73.

33. Dorman HJ, Peltoketo A, Hiltunen R, Tikkanen MJ. Characterisation of the antioxidant properties of deodourisation aqueous extracts from selected Lamiaceae herbs. Food Chem 2003;83:255-6.

34. Yildirim A, Mavi A, Oktay M, Kara AA, Algur OF, Bilaloglu V, et al. Comparison of antioxidant and antimicrobial activities of Tilia (Tilia argentea Desf ex DC), sage (Salvia triloba 1.), and black tea (Camellia sinensis) extracts. J Agric Food Chem 2000;48:5030-4.

35. Duh PD. Antioxidant activity of burdock (Arctium lappa Linne.): Its scavenging effect on free-radical and active oxygen. J Am Oil Chem Soc 1998;75:455-61

36. Duh PD, Du PC, Yen GC. The action of methanolic extract of mung beans hulls as inhibitors of lipid peroxidation and non-lipid oxidative damage. Food Chem Toxicol 1999;37:1055-61

37. Steenkamp V, Stewart MJ, Chimuka L, Cukrowska E. Uranium concentrations in South African herbal remedies. Health Phys 2005;89:679-83. 